\title{
Evaluation of training on brief interventions for teachers: health contributions
}

\author{
Avaliação da capacitação em intervenções breves para professores: contribuições da saúde \\ Evaluación de la capacitación en intervenciones breves para maestros: contribuciones de salud
}

Angelica Martins de Souza Gonçalves'

ORCID: 0000-0002-7265-5837

Sandra Cristina Pillon"

ORCID: 0000-0001-8902-7549

Rosa Jacinto Volpato'

ORCID: 0000-0001-5709-7008

Sônia Regina Zerbetto

ORCID: 0000-0002-2522-1948

Fernando José Guedes da Silva Júnior'll

ORCID: 0000-0001-5731-632X

'Universidade Federal de São Carlos. São Carlos, São Paulo, Brazil. "Universidade de São Paulo. Ribeirão Preto, São Paulo, Brazil.

"'Universidade Federal do Piaui. Teresina, Piauí, Brazil.

How to cite this article: Gonçalves AMS, Pillon SC, Volpato RJ, Zerbetto SR

Silva Jr FJG. Evaluation of training on brief interventions for teachers: health contributions.

Rev Bras Enferm. 2020;73(2):e20180108. doi: http://dx.doi.org/10.1590/0034-7167-2018-0108

Corresponding Author:

Angelica Martins de Souza Gonçalves E-mail: angelicamartins@ufscar.br

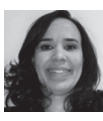

EDITOR IN CHIEF: Dulce Aparecida Barbosa ASSOCIATE EDITOR: Cristina Parada

Submission: 02-02-2018

Approval: 01-02-2019

\section{ABSTRACT}

Objectives: to evaluate the impact of training on brief interventions for use of substances on the attitudes; and, face validity and internal consistency of Brazilian versions of the Drug and Drug Problems Perceptions Questionnaire (DDPPQ-br) and the Short Alcohol and Alcohol Problems Perception Questionnaire (SAAPPQ) for use among teachers. Methods: methodological ( $N=122)$ and quasi-experimental study $(n=27)$. A sociodemographic questionnaire, the DDPPQ-br and the SAAPPQ were applied before and three months after the training. For analysis, were applied the Mann-Whitney and Wilcoxon tests. Results: the DDPQ-br and SAAPPQ were considered valid by experts. The training improved teachers attitudes towards accountability on the approach to substance use at schools and on the readiness to perform this role. In relation to drugs, it increased the perception of support. Conclusions: teachers' training can improve their attitudes and strengthen the school in the function of preventing substance-related harm.

Descriptors: Teacher Training; Health Knowledge, Attitudes, Practice; Street Drugs; Mental Health; Outcome Assessment (Health Care).

\section{RESUMO}

Objetivos: avaliar o impacto de uma capacitação em intervenções breves para o uso de substâncias sobreas atitudes evalidade defacee consistência interna das versões brasileiras Drug and Drug Problems Perceptions Questionnaire (DDPPQ-br) e Short Alcohol and Alcohol Problems Perception Questionnaire (SAAPPQ) entre professores. Métodos: estudo metodológico ( $N=122)$ e quase-experimental $(n=27)$. Foram aplicados o questionário sociodemográfico, o DDPPQbr e o SAAPPQ antes e três meses após a capacitação. Para análise, foram utilizados os testes de Mann-Whitney e de Wilcoxon. Resultados: O DDPQ-br e o SAAPPQ foram considerados válidos pelos especialistas. Através da capacitação, foi possível melhorar as atitudes frente a responsabilização sobre a abordagem do uso de substâncias na escola e o preparo para exercer tal função. Em relação às drogas, a percepção de suporte foi potencializada. Conclusões: Capacitar professores pode melhorar suas atitudes e fortalecer a escola na função de prevenir danos relacionados ao uso substâncias.

Descritores: Capacitação de Professores; Conhecimentos, Atitudes e Prática em Saúde; Drogas llícitas; Saúde Mental; Avaliação de Eficácia-Efetividade de Intervenções.

\section{RESUMEN}

Objetivos: evaluar el impacto de la capacitación en intervenciones breves para el uso de sustancias en las actitudes; $y$, la validez nominal y la consistencia interna de las versiones brasileñas del Drug and Drug Problems Perceptions Questionnaire (DDPPQ-br) y del Short Alcohol and Alcohol Problems Perception Questionnaire (SAAPPQ) entre los maestros. Métodos: investigación metodológica $(\mathrm{N}=122)$ y cuasi experimental $(n=27)$. Se aplicó un cuestionario sociodemográfico, el DDPPQ-br y el SAAPPQ, antes y tres meses después de la capacitación. Para el análisis, se utilizaron las pruebas de Mann-Whitney y Wilcoxon. Resultados: El DDPQ-br y el SAAPPQ fueron considerados válidos por los especialistas. La capacitación pudo mejorar las actitudes con respecto a la responsabilidad del enfoque del uso de sustancias en la escuela y la disposición para realizar esta función. En relación a las drogas, aumentó la percepción de apoyo. Conclusiones: capacitar a los maestros puede mejorar sus actitudes y fortalecer la escuela en la función de prevenir daños relacionados con el uso de sustancias.

Descriptores: Formación del Profesorado; Conocimientos, Actitudes y Práctica en Salud; Drogas Ilícitas; Salud Mental; Evaluación de Eficacia-Efectividad de Intervenciones. 


\section{INTRODUCTION}

In Brazil, the transition from the conception of drug issues from a justice problem to a public health problem is recent, dating back to 1990s, and tied to the advent of AIDS in the 1980s. At that time, the government understood that preventive actions, including those at schools, should address the issue in the routine and various facets of the use of psychoactive substances ${ }^{(1)}$.

The first initiatives were not designed for implementation in conjunction with the work of teachers and their basis were moralizing presumptions and the provision of information ${ }^{(1-2)}$. As of 2005, after promulgation of the National Drug Policy by the National Anti-Drug Council (Portuguese acronym: CONAD), was indicated the importance of intersectoral work by constructing care networks ${ }^{(3-4)}$.

Since the implementation of this policy, governmental initiatives have been created at various levels to address knowledge gaps of educators on the issue $e^{(5)}$. In practice, there is still a lack of scientific knowledge and access to information on the subject ${ }^{(6-7)}$.

In Brazil, courses for educators are usually publicized through joint actions with the National Secretariat for Drug Policy. Sometimes these courses are well evaluated by educators and achieve positive and transformative results ${ }^{(8)}$, despite their punctual promotion.

This fact, coupled with the fear of retaliation (from students, parents and traffickers in the school environment), commonsense based opinions and the understanding that this is work to be performed by health professionals ${ }^{(6,9-10)}$, interferes with the implementation of permanent programs for the prevention of use of alcohol and other drugs in Brazilian schools ${ }^{(6)}$. This is a sad reality, as epidemiological data on substance use among schoolchildren are alarming. In addition, a systematic review study on the evaluation of actions of this nature showed effective results in experimental research ${ }^{(11-12)}$.

Several measures are useful for evaluating strategies to prevent psychoactive substance use at schools. One is to measure educators' attitudes on this topic in their scope of work. Attitudes are evaluative responses created from the experiential process of the individual that can originate from personality traits or social determinants and be associated with cognitive and learning processes ${ }^{(13)}$. Previous studies had the aim to evaluate prevention programs for use of alcohol and other drugs at schools ${ }^{(14-15)}$, but did not evaluate primary and secondary school teachers. These professionals' attitudes towards this problem have not been evaluated either, whereas studies of this nature have been conducted more systematically among health professionals ${ }^{(16-19)}$.

Among instruments used to measure attitudes in the Brazilian context, are the Drug and Drug Problems Perceptions Questionnaire (DDPPQ-br) and the Short Alcohol and Alcohol Problems Perception Questionnaire (SAAPPQ). The DDPPQ-br assesses attitudes towards drug users and the SAAPPQ assesses attitudes in relation to alcohol user ${ }^{(20)}$. Both were tested and validated in a sample of Nursing students and are originated and based on the same theoretical reference of the Alcohol and Alcohol Problems Perceptions Questionnaire (AAPPQ).

The AAPPQ is an instrument adapted and validated in English (United Kingdom) that was developed to evaluate the Model of Therapeutic Commitment ${ }^{(21)}$. In this model, the therapeutic attitudes and bonding with users (of alcohol or other drugs) are influenced by: feeling of being prepared to adequately perform the care role, called "role adequacy"; extent to which individuals consider work as their responsibility ("role legitimacy"); and the support that practitioners recognize they receive from peers in order to help them play their role effectively ("support"). In this instrument, subscales were designed to evaluate the aforementioned model, which explains the attitudes regarding work with alcohol users: adequacy in function; role legitimacy; support; motivation; self-esteem; and satisfaction with working with these users ${ }^{(21-22)}$.

In addition to attitudes, another well studied topic among health professionals (given its relationship with Mental Health), but not among education professionals, are diagnostic strategies and brief interventions (Bls) for alcohol use related problems. These internationally disseminated strategies are a universal, simple and systematic resource for the prevention of use of alcohol and other drugs ${ }^{(23-24)}$. Brief interventions are based on behavioral and cognitive theories, use motivational techniques based on stages of readiness with the objective to detect the problem and motivate patients towards certain actions for reduction of psychoactive substance use ${ }^{(25)}$.

IBs have shown to be effective and stable for application to adult alcohol users ${ }^{(26)}$. In Brazil, they were successfully tested among adolescent users of marijuana, inhalants, ecstasy, alcohol and tobacco ${ }^{(27)}$. They can be a useful assistive tool in the work of various professionals, including secondary education teachers regarding the use of psychoactive substances as a transversal theme. The only requirement for implementation of these tools is training the professionals who will apply them ${ }^{(28)}$.

To date, training on screening and brief interventions has not been evaluated among teachers, which may be useful for reflecting on the applicability and dissemination of these strategies in school settings at appropriate times. For example, when teachers perceive students using psychoactive substances or to help with the creation of motivation actions for adopting behaviors that minimize the damages caused by substance use.

Evaluating educators' attitudes from this perspective can predict a greater or lesser chance of success of these interventions at schools. The hypothesis of the present study is that investing in training on brief intervention for problems related to psychoactive substances use can promote changes in teachers' attitudes towards their work with students experiencing such problems.

\section{OBJECTIVE}

To evaluate the impact of a training on brief interventions for use of psychoactive substances on attitudes of teachers; and face validity and internal consistency of the DDPPQ-br and SAAPPQ, Brazilian versions, for the use among teachers.

\section{METHOD}

\section{Ethical aspects}

The study was approved by the local Research Ethics Committee. The guidelines recommended by Resolution number 466, 
December $12^{\text {th }}, 2012$ of the National Health Council, Brazil were respected. All participants signed the Informed Consent form.

\section{Design, place of study and period}

The present study was conducted in two methodological stages. The first was the instrument evaluation ${ }^{(29)}$ and the other involved the quasi-experimental method and pre-and post-test evaluation ${ }^{(30)}$. The instrument evaluation included: (1) face validity, which is useful to check the clarity of the translation process by review and a panel of experts; and (2) reliability assessment by internal consistency, which shows how much the subscale items are related when evaluating the same construct ${ }^{(29)}$ of the Brazilian versions of the SAAPPQ and DDPPQ-br for use among teachers. Quasi-experimental studies are used to evaluate interventions without designated random sample and allow some reliability between cause and effect relationships ${ }^{(30)}$. The data collection period was from September to December 2016.

\section{Sample and inclusion and exclusion criteria}

Non-probabilistic sampling. Participation of 122 primary and secondary school teachers from four Brazilian public schools in the study, of which three located in the inlands of the state of São Paulo and one in the state of Mato Grosso. Of these teachers, 27 made up the sample of the quasi-experimental stage of the study. The eligibility criteria were: teachers of both sexes, working in primary or secondary schools and a teaching time of more than six months. In the quasi-experimental stage, the exclusion criteria were: no full participation in the educational intervention and participation in some other course or training on prevention of alcohol and drug use at school before the second stage of data collection.

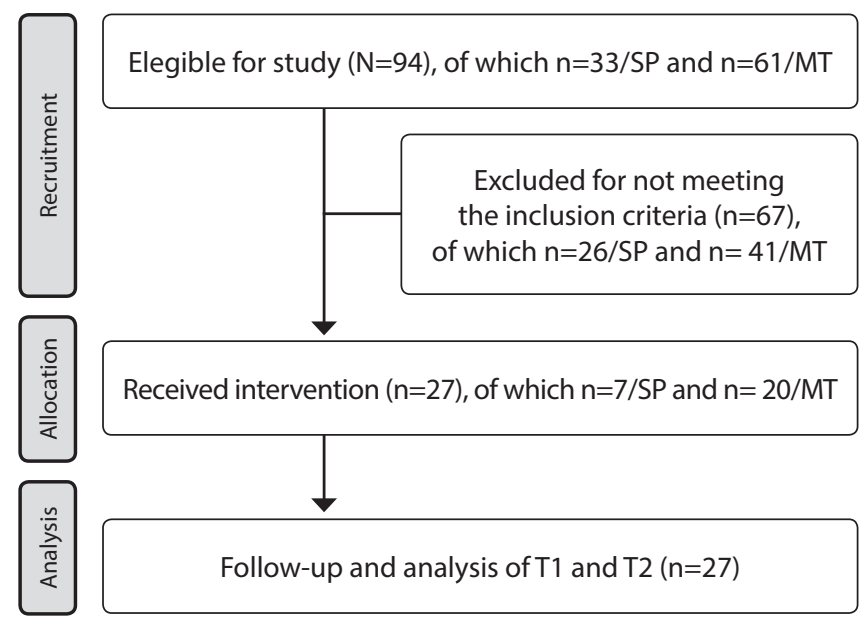

Figure 1 - Information on the recruitment of participants, adapted from CONSORT 2010 (31)

\section{Study protocol}

Some adjustments were necessary in the stage of instrument evaluation. The term "patients" was replaced by "students" in the DDPPQ-br and SAAPPQ. Subsequently, the version was sent to a committee of three researchers of the area of alcohol and drugs with experience in adaptation and validation of instruments (a social worker and two nurses). There were no semantic changes in the items and both instruments were deemed appropriate by judges. Then, the instruments were tested with two individuals in the target population (one primary and one secondary school teacher) and again, there were no doubts nor suggestions for changes.

The pre-test evaluation was carried out with teachers in the quasi-experimental stage. They assessed their attitudes toward working with students using psychoactive substances (dependent variable). Next, the contents of the brief intervention training as a means of preventing alcohol and other drug use for educators was adapted and applied in the context of an educational intervention (independent variable).

After three months, the same variables were measured again by considering that the purpose of this training was that teachers were able to carry out screening activities (identification) and apply intervention strategies at the school in a preventive way (with Bls principles). It was evaluated if the knowledge and information acquired by teachers during the intervention generated changes in their attitudes.

The intervention consisted of 12 hours of lectures and dialogic classes and included the following contents: (1) epidemiology of the main psychoactive substances used by adolescents in the Brazilian context and its consequences; factors of risk and protection associated with consumption; (2) prevention strategies of drug abuse in the school context; (3) substance use screening and (4) brief interventions at school. In the third class, the Alcohol, Smoking and Substance Involvement Screening Test (ASSIST) was used as a reference, since it has been useful in identifying the use of several substances in life and in the three prior months, including injectable drugs ${ }^{(32)}$.

The developed questionnaire included the following: 1) sociodemographic information with the variables of age, sex, religion, discipline taught and time of experience in the profession.

2) Drug and Drug Problems Perceptions Questionnaire (DDPPQbr), Brazilian version, assesses attitudes toward work with drug users (except alcohol and tobacco). This version is composed of five domains (role adequacy; support; job satisfaction; self-esteem; and legitimacy), as in the original English version ${ }^{(22)}$ and presents a good level of internal consistency (Cronbach's alpha=0.85). The answers are self-reported, statements are of the Likert type and range from zero (0) - totally agree to seven (7) - strongly disagree. For the calculation of DDDPQ-br scores, items 13, 15, 16 and 17 were inverted and then added up. The items assess if the knowledge acquired is enough for the following: performing their professional role; preparing to intervene and adequately advise people with problems related to drug use; feeling support to perform such roles; and the internal availability to address this topic in the work context. The higher the sum of scores, the worse or the more negative the attitudes towards the issue ${ }^{(22)}$.

3) The Short Alcohol and Alcohol Problems Perception Questionnaire (SAAPPQ) assesses perceptions and attitudes toward work with people who have problems related to alcohol use or alcohol dependence. It was validated for Portuguese (including Brazil, where the study involved Nursing students). It has the following domains: adequacy; motivation (desire to work with alcohol users); legitimacy; satisfaction and self-esteem. The instrument has good indices of global internal consistency (Cronbach's 
alpha=0.87). It is self-applicable and has 10 statements, where respondents indicate their level of agreement or disagreement; 1 point indicates strongly disagree, 3 points is neutral, and 5 points indicates totally agree. Items 3, 4 and 6 of the SAAPPQ were reversed. The higher the score the more positive the attitude toward work with the problem of alcohol use $\mathrm{e}^{(33)}$.

Both instruments do not have cutoff points because sensitivity and specificity were not assessed. The evaluation is done through comparison between groups by means of the average score.

\section{Analysis of results and statistics}

A database was prepared in Microsoft Excel 2000 and the Statistical Package for the Social Sciences, version 19.0 (license number 10250887) was used. Descriptive statistics were used to evaluate sociodemographic data (measures of central tendency and dispersion). For evaluation of distribution of data to normality, was used the Shapiro-Wilk Test. After this test, to check the association between qualitative and quantitative variables with a description of two groups, the Mann-Whitney and Wilcoxon tests were used in the evaluation of the same variable at different moments (both in the absence of normal data distribution). The significance level of $5 \%$ was adopted for all tests.

\section{RESULTS}

In the methodological stage of the study, most of the sample was of women, 88 in total (72.1\%), adults, mean age of $40.4 \pm 9.1$ years, ranging from 21 to 64 years. Teachers have been teaching for $120.8 \pm 92.3$ months on average. Table 1 shows the distribution of teachers by the fields investigated.
The internal consistency indices measured by the Cronbach's Alpha were SAAPPQ $=0.58$ and DDPPQ-br $=0.84$, both considered valid by the experts (face validity).

In the quasi-experimental stage, of the 27 participants, 20 (74\%) were teachers from Mato Grosso and seven (26\%) from São Paulo. Most were women (74.1\%), adults, mean age of $36.9 \pm 7.7$ years, ranging from 26 to 54 years, had been teaching for $10 \pm 7.5$ years (average) in the same school and $48.1 \%$ had already participated in some alcohol and drug training course during their professional life.

In the evaluation of attitudes measured pre- and post-intervention (Table 2), teachers presented higher mean values in "Adequacy" [post 6.4 \pm 1.2 versus pre 4.9 $\pm 1.6 ; p<0.001$ ] and "Legitimacy" [post $6.7 \pm 1.1$ versus pre $6.0 \pm 1.3 ; p=0.039$ ] subscales of the SAPPQ, which represents positive attitudes in the performance of these roles. However, the attitudes did not differ in the subscales "Self-esteem", "Motivation" and "Satisfaction" in the comparison between pre- and post-intervention.

In the DDPPQ-br, positive attitudes were observed postintervention with lower mean values in subscales "Adequacy" [post $24.6 \pm 5.7$ versus pre 34.7 $\pm 7.8 ; p<0.001$ ], "Support" [post 12.8 \pm 3.1 versus pre 14.8 $\pm 4.3 ; p=0.020$ ] and "Legitimacy" [post 7.2 \pm 2.7 versus pre $9.4 \pm 2,9 ; p=0.020$ ] and statistically significant values.

When comparing the SAPPQ and DAPPQ subscales presented in Table 3, there were no significant differences when evaluating the SAPPQ and the presence of some training on alcohol and/or drug at school, both in pre- and post-intervention groups. However, teachers in the pre-intervention group, who had some type of training throughout their professional life, presented positive attitudes towards Work (DAPPQ), and in the post-intervention group, in relation to Work and Support (DAPPQ).

Table 1 - Distribution of teachers (methodological study) by city, school and area of activity, São Paulo and Mato Grosso, Brazil, 2016

\begin{tabular}{|c|c|c|c|c|c|c|c|c|c|c|c|c|c|c|c|c|}
\hline \multirow{3}{*}{ Area } & \multicolumn{4}{|c|}{$\begin{array}{c}\text { City } 1 \\
\text { SP }\end{array}$} & \multicolumn{4}{|c|}{$\begin{array}{c}\text { City } 2 \\
\text { SP }\end{array}$} & \multirow{2}{*}{\multicolumn{2}{|c|}{$\begin{array}{c}\text { City } 3 \\
\text { SP } \\
\text { School } 5\end{array}$}} & \multicolumn{4}{|c|}{$\begin{array}{c}\text { City } 4 \\
\text { MT }\end{array}$} & \multirow{2}{*}{\multicolumn{2}{|c|}{ Total }} \\
\hline & \multicolumn{2}{|c|}{ School 1} & \multicolumn{2}{|c|}{ School 2} & \multicolumn{2}{|c|}{ School 3} & \multicolumn{2}{|c|}{ School 4} & & & \multicolumn{2}{|c|}{ School 6} & \multicolumn{2}{|c|}{ School 7} & & \\
\hline & $\mathbf{n}$ & $\%$ & $\mathbf{n}$ & $\%$ & $\mathbf{n}$ & $\%$ & $\mathbf{n}$ & $\%$ & $\mathbf{n}$ & $\%$ & $\mathbf{n}$ & $\%$ & $\mathbf{n}$ & $\%$ & n & $\%$ \\
\hline Biological & 5 & 4.1 & 4 & 3.3 & 4 & 3.3 & 4 & 3.3 & 4 & 3.3 & 2 & 1.6 & 3 & 2.5 & 26 & 21.4 \\
\hline Human & 17 & 14 & 7 & 5.7 & 12 & 9.8 & 10 & 8.2 & 12 & 9.8 & 6 & 5 & 2 & 1.6 & 66 & 54.1 \\
\hline Exact & 2 & 1.6 & 3 & 2.5 & 3 & 2.5 & 2 & 1.6 & 3 & 2.5 & 1 & 0.8 & 2 & 1.6 & 16 & 13.1 \\
\hline Polyvalent & 2 & 1.6 & 0 & 0 & 1 & 0.8 & 5 & 4.1 & 1 & 0.8 & 2 & 1.6 & 3 & 2.5 & 14 & 11.4 \\
\hline Total & 26 & 21.3 & 14 & 11.5 & 20 & 16.4 & 21 & 17.2 & 20 & 16.4 & 11 & 9 & 10 & 8.2 & 122 & 100 \\
\hline
\end{tabular}

Table 2 - Comparison of Short Alcohol and Alcohol Problems Perception Questionnaire (SAAPPQ) and Drug and Drug Problems Perceptions Questionnaire (DDPPQ-br) subscales scores in the pre- and post-intervention ( $n=27)$, according to secondary and primary school teachers, São Paulo and Mato Grosso, Brazil, 2016

\begin{tabular}{|c|c|c|c|c|}
\hline & & $\begin{array}{c}\text { Pre-intervention }(\mathbf{n}=\mathbf{2 7}) \\
\text { Mean } \pm \text { SD }\end{array}$ & $\begin{array}{c}\text { Post-intervention }(\mathbf{n}=\mathbf{2 7}) \\
\text { Mean } \pm \text { SD }\end{array}$ & $p$ value \\
\hline SAPPQ & $\begin{array}{l}\text { Adequacy } \\
\text { Self-esteem } \\
\text { Motivation } \\
\text { Legitimacy } \\
\text { Satisfaction }\end{array}$ & $\begin{array}{l}4.9 \pm 1.6 \\
5.9 \pm 1.2 \\
5.7 \pm 1.3 \\
6.0 \pm 1.3 \\
4.8 \pm 1.9\end{array}$ & $\begin{array}{l}6.4 \pm 1.2 \\
6.6 \pm 1.5 \\
5.6 \pm 1.4 \\
6.7 \pm 1.1 \\
4.9 \pm 1.4\end{array}$ & $\begin{array}{c}<\mathbf{0 . 0 0 1} \\
0.055 \\
0.729 \\
0.039 \\
0.565\end{array}$ \\
\hline DAPPQ-br & $\begin{array}{l}\text { Adequacy } \\
\text { Support } \\
\text { Satisfaction } \\
\text { Self-esteem } \\
\text { Legitimacy }\end{array}$ & $\begin{array}{c}34.7 \pm 7.8 \\
14.8 \pm 4.3 \\
18.6 \pm 4.1 \\
13.5 \pm 3.8 \\
9.4 \pm 2.9\end{array}$ & $\begin{array}{c}24.6 \pm 5.7 \\
12.8 \pm 3.1 \\
17.0 \pm 3.5 \\
12.2 \pm 3.3 \\
7.2 \pm 2.7\end{array}$ & $\begin{array}{c}<0.001 \\
0.020 \\
0.096 \\
0.166 \\
0.002\end{array}$ \\
\hline
\end{tabular}

Note: Wilcoxon Test; Pvalue<0.001; SAAPPQ - Short Alcohol and Alcohol Problems Perception Questionnaire; DDPPQ-br - Drug and Drug Problems Perceptions Questionnaire. 
Table 3 - Previous training on alcohol and drugs, São Paulo and Mato Grosso, Brazil, 2016

\begin{tabular}{|c|c|c|c|c|c|c|}
\hline & & \multirow[b]{2}{*}{ Training } & \multicolumn{2}{|c|}{ Pre-intervention } & \multicolumn{2}{|c|}{ Post-intervention } \\
\hline & & & Mean score & $p$ value & Mean score & $p$ value \\
\hline \multirow{10}{*}{ SAPPQ } & \multirow{2}{*}{ Adequacy } & Yes & 15.3 & \multirow{2}{*}{0.388} & 14.3 & \multirow{2}{*}{0.861} \\
\hline & & No & 12.7 & & 13.7 & \\
\hline & \multirow{2}{*}{ Self-esteem } & Yes & 13.2 & \multirow{2}{*}{0.613} & 12.8 & \multirow{2}{*}{0.472} \\
\hline & & No & 14.7 & & 15.0 & \\
\hline & \multirow{2}{*}{ Motivation } & Yes & 11.8 & \multirow{2}{*}{0.166} & 12.7 & \multirow[b]{2}{*}{0.597} \\
\hline & & No & 15.9 & & 14.3 & \\
\hline & \multirow{2}{*}{ Legitimacy } & Yes & 15.0 & \multirow{2}{*}{0.514} & 14.4 & \multirow{2}{*}{0.761} \\
\hline & & No & 13.0 & & 13.5 & \\
\hline & \multirow{2}{*}{ Satisfaction } & Yes & 11.7 & \multirow{2}{*}{0.155} & 14.8 & \multirow{2}{*}{0.556} \\
\hline & & No & 16.0 & & 13.1 & \\
\hline \multirow{9}{*}{ DAPPQ } & \multirow{2}{*}{ Adequacy } & Yes & 12.5 & \multirow{2}{*}{0.343} & 12.5 & \multirow{2}{*}{0.515} \\
\hline & & No & 15.3 & & 14.4 & \\
\hline & \multirow{2}{*}{ Support } & Yes & 12.6 & \multirow{2}{*}{0.377} & 10.8 & \multirow{2}{*}{0.044} \\
\hline & & No & 15.2 & & 16.9 & \\
\hline & Work & Yes & 8.9 & \multirow{2}{*}{0.004} & 10.8 & \multirow{2}{*}{0.043} \\
\hline & \multirow{2}{*}{ Self-esteem } & No & 17.4 & & 16.9 & \\
\hline & & Yes & 13.2 & \multirow{2}{*}{0.891} & 13.6 & 0.807 \\
\hline & \multirow[b]{2}{*}{ Legitimacy } & $\begin{array}{l}\text { No } \\
\text { Yes }\end{array}$ & $\begin{array}{l}12.8 \\
15.6\end{array}$ & & $\begin{array}{l}14.3 \\
13.5\end{array}$ & \multirow{2}{*}{0.746} \\
\hline & & No & 12.5 & 0.302 & 14.4 & \\
\hline
\end{tabular}

Note: Teste Mann-Whitney; Valor de $p<0,001 ;$ SAAPPQ - Short Alcohol and Alcohol Problems Perception Questionnaire; DDPPQ-br - Drug and Drug Problems Perceptions Questionnaire.

\section{DISCUSSION}

The instruments used to assess the attitudes in the present study can be applied to secondary school teachers. The face validity of both was considered adequate by the panel of experts. The level of internal consistency of the DDPPQ-br was considered good (0.80-0.89) and close to its Brazilian version tested among Nursing students, which was 0.85 . The internal consistency of the SAAPPQ was considered poor, but acceptable (0.50-0.59) ${ }^{(29)}$. The coefficient values found in the scales derived from the AAPPQ ranged from 0.69 to $0.94^{(34)}$.

In general, the quasi-experimental study stage confirmed the hypothesis of the study and ratified the well-known effect of educational interventions on the change of attitudes related to work with the use of psychoactive substances ${ }^{(35)}$. However, this finding for the area of education opens a new panorama of discussion for the area of Health as a promoter of changes in attitudes of professionals from other areas with potential consequences to changes in practice, in this case, of these educators.

In this study, the intervention in screening and brief interventions for teachers broadened teachers' sense of accountability (legitimacy) regarding the approach to alcohol and drug use at schools, as well as their adequate preparation and knowledge (adequacy) to perform this role. Only in relation to drugs, the perception of support was potentiated, that is, of being able to count on some additional resource to face the problem. In a previous study, was emphasized the importance of these attributes for providing adequate and effective care in the area of alcohol and drugs ${ }^{(36)}$. The lack of adequate training represents an important barrier to address this issue in work contexts, because of its relationship with levels of confidence, discomfort and inadequate attitudes, which distract professionals from the important role of preventive intervention ${ }^{(37)}$.
As educators also prevent several types of harm simultaneously, they must be strengthened through continued education investments on specific topics, such as brief interventions for substance use. The school is considered a health interface environment, where actions such as screening, referrals and educational activities can be undertaken ${ }^{(38)}$. The findings of this research suggest that especially for the use of other drugs (other than alcohol), attitudes related to job satisfaction and the recognition of support are fundamental for performing these practices, which can be better developed through more than one training event. In a previous study, nursing students were offered a training on the subject, but divergent results were found and the intervention had more positive effects on attitudes toward alcohol than other drugs ${ }^{(37)}$.

The improvement of attitudes coupled with the dissemination of screening strategies and brief interventions for use of psychoactive substances among educators can increase their accountability before the theme, minimize their fear of addressing this issue at school (linked to the lack of theoretical knowledge and access to information on the theme), fear of retaliation (from students, parents and traffickers in the school setting), and facilitate the understanding that this matter is a job to be performed not only by professionals specialized in the area of Mental Health ${ }^{(10)}$.

\section{Limitations of the study}

The limitations of the study involve checking validity and reliability of the SAAPPQ and DDPPQ-br instruments among teachers, which was performed only by face validity (simpler and weaker) ${ }^{(29)}$, and internal consistency. Other measures and analyzes can be evaluated in future studies for more robust results. In the case of SAAPPQ, reformulating some items could improve its internal coherence.

In the quasi-experimental phase, limitations are inherent in its design, since there can always be other intervening variables, besides the applied intervention ${ }^{(30)}$.

\section{Contributions to the area of nursing, health or public policy}

The findings show the potential impact of training on screening and brief interventions on attitudes of professionals outside the health area, since this universal tool can be used in different contexts ${ }^{(28)}$, cooperate with the understanding of how and in what contexts these strategies can work and what their real effectiveness is, which is a gap raised in the scientific literature ${ }^{(39)}$. In a previous study, actions to prevent the use of substances were mentioned as more effective when implemented by teachers than those offered by specialists ${ }^{(15)}$. This reinforces the need to disseminate brief interventions among teachers, and nurses are the most recommended professionals for this purpose, given their competence in performing health education actions ${ }^{(28)}$. 


\section{CONCLUSION}

The SAAPPQ and DDPPQ-br instruments can be used among teachers, despite the low level of internal consistency of the SAAPPQ. The educational intervention in screening and brief interventions was effective in improving teachers' attitudes towards accountability (legitimacy) of approaching the use of alcohol and drugs at school and in the preparation (adequacy) to perform this role. In relation to drugs, the perception of support to face the problem got better.

Another conclusion was that attitudes related to the feeling of work satisfaction and the recognition of support are better developed through an education process not restricted to a single educational intervention. The dissemination of strategies of this nature by health professionals (especially nurses) in a school setting can strengthen the role of this place as a health education space. Another implication is related to the reflection on how brief interventions can work effectively in the school routine with the promotion of changes through educators in relation to the use of psychoactive substances by their students.

\section{FUNDING}

We appreciate National Council of Scientific and Technological Development (Portuguese acronym: CNPq) for the financial support and scholarship grant.

\section{REFERENCES}

1. Machado LV, Boarini ML. Políticas sobre drogas no Brasil: a estratégia de redução de danos. Psicol Ciênc Prof. 2013;33(3):580-95. doi: $10.1590 /$ S1414-98932013000300006

2. Albertani HMB, Sodelli M. Drogas e educação: a escola (real) e a prevenção (possível). In.: Ronzani TM, Silveira PS, organizadoras. Prevenção ao uso de álcool e outras drogas no contexto escolar. Juiz de Fora: Ed. UFJF; 2014 [cited 2018 Feb 16]. p. 133-55. Available from: http://sisco. copolad.eu/web/uploads/documentos/Prevencao_ao_uso_de_alcool_e_outras_drogas_no_contexto_escolar.pdf

3. Manfrê MM. Redes de atenção aos usuários de álcool e outras drogas: a visão dos trabalhadores e gestores de serviços de saúde mental de um município do Estado de São Paulo. Rev Psicol UNESP [Internet]. 2015 [cited 2018 Feb 16];14(1):26-37. Available from: http://pepsic. bvsalud.org/scielo.php?script=sci_arttext\&pid=S1984-90442015000100003

4. Varela DSS, Sales IMM, Silva FMD, Monteiro CFS. Health network assisting users of alcohol, crack, and other drugs. Esc Anna Nery. 2016;20(2):296-302. doi: 10.5935/1414-8145.20160040

5. Giacomozzi Al, Itokasu MC, Luzardo AR, Figueiredo CDS, Vieira M. Levantamento sobre uso de álcool e outras drogas e vulnerabilidades relacionadas de estudantes de escolas públicas participantes do programa saúde do escolar/saúde e prevenção nas escolas no município de Florianópolis. Saúde Soc. 2012;21(3):612-22. doi: 10.1590/S0104-12902012000300008

6. Silva PMC, Galon T, Zerbetto SR, Moura AAM, Volpato RJ, Gonçalves AMS. Teachers' perceptions, difficulties, and actions facing drugs at the school environment. Educ Pesqui. 2018;44:e182015. doi: 10.1590/s1678-4634201844182015

7. Moreira A, Lemos VC, Micheli D. Drug abuse prevention in school: challenges and possibilities for the role of the educator. Educ Pesqui. 2015;41(1):119-34. doi: 10.1590/S1517-97022015011670

8. Chagas JC, Marques RHB, Pedroza RLS, Pulino LHCZ, Silva SFL, Siqueira IB, et al. Concepções de professoras dos anos iniciais do ensino fundamental sobre prevenção do uso indevido de drogas. Rev Bras Educ. 2017;22(71):e227179. doi: 10.1590/s1413-24782017227179

9. Cattoni AJ, Njaine K, Oliveira MC, Ghizoni AC. Representações sociais de professores sobre o uso abusivo de álcool e outras drogas na adolescência: repercussões nas ações de prevenção na escola. Interface (Botucatu). 2012;16(40):135-46. doi: 10.1590/S1414-32832012005000002

10. Nascimento MO, Vitalle S, Avallone DM. A Visão e temores dos educadores ante ao uso abusivo de substâncias psicoativas por adolescentes no ambiente escolar. Rev Magistro [Internet] 2012. [cited 2018 Feb 10];2(1):5-21. Available from: http://publicacoes.unigranrio.edu.br/index. $\mathrm{php} / \mathrm{magistro0/article/view/1684/926}$

11. Instituto Brasileiro de Geografia e Estatística (IBGE). Pesquisa Nacional de Saúde do Escolar: 2015 [Internet]. Rio de Janeiro: IBGE; 2016 [cited 2018 Feb 10]. Available from: http://biblioteca.ibge.gov.br/visualizacao/livros/liv97870.pdf

12. Faggiano F, Minozzi S, Versino E, Buscemi D. Universal school-based prevention for illicit drug use. Cochrane Database Syst Rev. 2014;(12):CD003020. doi: 10.1002/14651858.CD003020.pub3

13. Harling MR, Turner W. Student nurses' attitudes to illicit drugs: a grounded theory study. Nurse Educ Today. 2012;32(3):235-40. doi: 10.1016/j. nedt.2011.05.002

14. Guo JL, Lee TC, Liao JY, Huang CM. Prevention of illicit drug use through a school-based program: results of a longitudinal, clusterrandomized controlled trial. J Adolesc Health. 2015;56(3):314-22. doi: 10.1016/j.jadohealth.2014.12.003

15. Nascimento MO, Micheli D. Evaluation of different school-based preventive interventions for reducing the use of psychotropic substances among students: a randomized study. Ciênc Saúde Colet. 2015;20(8):2499-510. doi: 10.1590/1413-81232015208.15152014

16. Junqueira MAB, Rassool GH, Santos MA, Pillon SC. The Impact of an educational program in brief interventions for alcohol problems on undergraduate nursing students. J Addict Nurs. 2015;26(3):129-35. doi: 10.1097/JAN.0000000000000086

17. Soares J, Vargas D, Formigoni MLOS. Knowledge and attitudes of nurses towards alcohol and related problems: the impact of an educational intervention. Rev Esc Enferm USP. 2013;47(5):1172-85. doi: 10.1590/S0080-623420130000500023 
18. Evers C, Ploeg J, Kaasalainen S. Case study of the attitudes and values of nursing students toward caring for older adults. J Nurs Educ. 2011;50(7):404-9. doi: 10.3928/01484834-20110429-03

19. Rajkumar E, Julious S, Salome A, Jennifer G, John AS, Kannan L, et al. Effects of environment and education on knowledge and attitude of nursing students towards leprosy. Indian J Lepr [Internet]. 2011 [cited 2018 Feb 10];83(1):37-43. Available from: http://www.ijl.org.in/janmarch-2011/6\%20-\%20Rajkumar\%20et\%20al\%2037-43.pdf

20. Gonçalves AMS, Santos MA, Volpato RMJ, Furtado EF, Barroso TMMDA, Pillon SC. Attitudes of nursing students towards substance user and perceptions about religious/spiritual care. Rev Esc Enferm USP. 2018;52:e03425. doi: 10.1590/s1980-220x2017027903425

21. Terhorst L, Gotham HJ, Puskar KR, Mitchell AM, Talcott KS, Braxter B, et al. Confirming the factor structure of the alcohol and alcohol problems questionnaire (AAPPQ) in a sample of baccalaureate nursing students. Res Nurs Health. 2013;36(4):412-22. doi: 10.1002/nur.21537

22. Watson H, Maclaren W, Kerr S. Staff attitudes towards working with drug users: development of the Drug Problems Perceptions Questionnaire. Addiction. 2007;102(2):206-15. doi: 10.1111/j.1360-0443.2006.01686.x

23. Wardell JD, Read JP, Curtin JJ, Merrill JE. Mood and implicit alcohol expectancy processes: predicting alcohol consumption in the laboratory. Alcohol Clin Exp Res. 2012;36(1):119-29. doi: 10.1111/j.1530-0277.2011.01589.x

24. Scott-Sheldon LA, Terry DL, Carey KB, Garey L, Carey MP. Efficacy of expectancy challenge interventions to reduce college student drinking: A meta-analytic review. Psychol Addict Behav. 2012;26(3):393-405. doi: 10.1037/a0027565

25. Marques ACPR, Furtado EF. Brief interventions for alcohol related problems. Rev Bras Psiquiatr. 2004;26(1):28-32. doi: 10.1590/ S1516-44462004000500008

26. Heather N. Interpreting null findings from trials of alcohol brief interventions. Front Psychiatry. 2014;5:85. doi: 10.3389/fpsyt.2014.00085

27. Micheli D, Fisberg M, Souza-Formigoni MLOD. Estudo da efetividade da intervenção breve para o uso de álcool e outras drogas em adolescentes atendidos num serviço de assistência primária à saúde. Rev Assoc Med Bras. 2004;50(3):305-13. doi: 10.1590/ S0104-42302004000300040

28. Gonçalves MAS, Ferreira PS, Abreu AMM, Pillon SC, Jezus SV. Estratégias de rastreamento e intervenções breves como possibilidades para a prática preventiva do enfermeiro. Rev Eletr Enf. 2011;13(2):355-60. doi: 10.5216/ree.v13i2.10502

29. Arafat SY, Chowdhury HR, Qusar MMAS, Hafez MA. Cross cultural adaptation \& psychometric validation of research instruments: A methodological review. J Behav Health. 2016;5(3):129-36. doi: 10.5455/jbh.20160615121755

30. Cook TD, Campbell DT, Shadish W. Experimental and Quasi-experimental designs for generalized causal inference [Internet]. Boston: Houghton Mifflin Company; 2002 [cited 2018 Fev 09]. Available from: https://www.alnap.org/system/files/content/resource/files/main/147.pdf

31. Schulz KF, Altman DG, Moher D. CONSORT 2010 statement: updated guidelines for reporting parallel group randomised trials. BMJ. 2010;340:c332. doi: 10.1136/bmj.c332

32. Silva AC, Lucchese R, Vargas LS, Benício PR, Vera I. Application of the Alcohol, Smoking and Substance Involvement Screening Test (ASSIST) instrument: an integrative review. Rev Gaúcha Enferm. 2016;37(1):e52918. doi: 10.1590/1983-1447.2016.01.52918

33. Santos G, Rosário F. Attitudes of family medicine residents towards patients with alcohol-related problems. Rev Port Med Geral Fam [Internet]. 2015 [cited 2018 Fev 22];31(6):376-382. Available from: http://www.scielo.mec.pt/pdf/rpmgf/v31n6/v31n6a04.pdf

34. Pasche S, Myers B, Louw J. Staff attitudes and services provided by community-based organizations for alcohol and other drug users in Cape Town, South Africa: Implications for training and education. Drugs (Abingdon Engl). 2008;15(6):532-44. doi: 10.1080/0968763070161070

35. Vargas D, Soares J. Atitudes de enfermeiros frente ao alcoolismo: revisão da literatura. Cogitare Enferm [Internet]. 2011;16(2):340-7. Available from: https://revistas.ufpr.br/cogitare/article/view/17619

36. Nkowane AM, Saxena S. Opportunities for an improved role for nurses in psychoactive substance use: review of the literature. Int J Nurs Pract. 2004;10(3):102-10. doi: 10.1111/j.1440-172X.2004.00471.x

37. Puskar K, Gotham HJ, Terhorst L, Hagle H, Mitchell AM, Braxter B, et al. Effects of screening, brief intervention, and referral to treatment (SBIRT) education and training on nursing students' attitudes toward working with patients who use alcohol and drugs. Subst Abus. 2013;34(2):122-8. doi: 10.1080/08897077.2012.715621

38. Casemiro JP, Fonseca ABC, Secco FVM. Promoting health in school: reflections based on a review of school health in Latin America. Ciênc Saúde Colet. 2014;19(3):829-40. doi: 10.1590/1413-81232014193.00442013

39. Glass JE, Andréasson S, Bradley KA, Finn SW, Williams EC, Bakshi AS. Rethinking alcohol interventions in health care: A thematic meeting of the International Network on Brief Interventions for Alcohol \& Other Drugs (INEBRIA). Addict Sci Clin Pract. 2017;12(1):14. doi: 10.1186/s13722-017-0079-8 